\title{
Effect of Green Manure and Neem Oil on Anthracnose Disease of Chilli (Capsicum annuum L.)
}

\author{
Veeramreddy Srilekha*, Sobita Simon and Sunil Zacharia
}

Naini Agricultural Institute, Sam Higginbottom University of Agriculture Technology and Sciences, Prayagraj and Uttar Pradesh, India

*Corresponding author

\section{A B S T R A C T}

K e y w o r d s
Chilli, Anthracnose,
Colletotrichum
capsici, Green
manure, Rhizobium,
Neem oil

Chilli (Capsicum annuum L.) is an important vegetable crop, cultivated around the world. Among different fungal diseases of Chilli, anthracnose caused by Colletotrichum capsici has currently become important disease for yield loss. An attempt was therefore made to, isolation Rhizobium from the collected rhizosphere soil samples from research plot. Where, the populations of rhizobia were counted and were found maximum at post sowing stage. Therefore, effect of green manures (Cowpea, Sunhemp, Dhaincha, Green gram, Black gram, Cluster bean) with two foliar spray of neem oil@0.5\% used against Colletotrichum capsici of anthracnose in chilli and growth parameters of chilli. Seven treatments were under taken with three replications and data was analyzed using RBD. Minimum disease intensity was recorded in $\mathrm{T}_{4}-$ Sun hemp+ neem oil (25.79\%) and maximum Yield $\mathrm{T}_{4}$ - Sun hemp + neem oil $\left(90.23 \mathrm{q} / \mathrm{ha}\right.$ ) followed by $\mathrm{T}_{6}$-Dhaincha+neem oil $(26.63 \%)$ with Yield $(90.03 q / h a), \mathrm{T}_{\mathbf{5}}$ - Cluster bean + Neem oil $(28.63 \%)$ with yield $(84 \mathrm{q} / \mathrm{ha}), \mathrm{T}_{1}$ - Cowpea + Neem oil $(33.36 \%)$ with yield $(79.47 \mathrm{q} / \mathrm{ha}), \mathrm{T}_{2}$-Black gram + Neem oil $(29.57 \%)$ with yield $(72.20 \mathrm{q} / \mathrm{ha}), \mathrm{T}_{3}$-Green gram $+\mathrm{Neem}$ oil $(31.56 \%)$ with yield $(65.70 \mathrm{q} / \mathrm{ha})$ maximum disease intensity was recorded in control $(43.40 \%)$ and lowest yield (49.47q/ha).

\section{Introduction}

Chilli (Capsicum annuum L.) is an important vegetable and spice crop, cultivated around the world. It is not only used in cooking but also found to have many medicinal properties. The genus Capsicum contain about 20-25 species, out of which $C$. annuum, $C$. baccatum, $C$. chinense, $C$. frutescens and $C$. pubescens are cultivated. Capsicum annuum was widely cultivated variety, second being C. frutescens (Sahitya et al., 2014). India contributes $25 \%$ of the world's total production of chilli. In India, chilli was mainly grown in states like Andhra Pradesh, Maharashtra, Karnataka, Gujarat, Tamil Nadu and Orissa (Lydia and Zacharia, 2012). Chilli has been affected by several diseases like fungal, bacterial and viral of which, chilli anthracnose causes significant damage, impose severe quantitative and qualitative losses. The estimated loss due to this disease is ranged from 8 to $60 \%$ in different parts of India. The disease symptoms can occur on 
leaves, stems, and both pre- and post-harvest fruits. Typical anthracnose symptoms on chilli fruit include sunken necrotic tissues, with concentric rings of acervuli (Agrios, 2005). The fungus pathogen is both seed borne and air borne and affects seed germination and vigour to a greater extent (Gopinath et al., 2006; Shovan et al., 2008). Currently the disease is mostly managed by using chemical fungicides. The continuous and indiscriminate use of fungicides leads to toxic residues on chilli products, development of fungicide resistance and also serves as a cause for environmental pollution (Suji and Raj 2015). To overcome the undesirable effects of chemical usage, use of green manure amendments and neem oil to control the infection came at rescue. Investigations proved that application of green manure amendments significantly reduced the fruit rot incidence and enhanced the fruit yield and dry matter production.

Green manure is a type of cover crop grown primarily for two months that is meant to incorporated into the soil to improve the nitrogen supply and use of application enhances soil productivity, increases the soil organic carbon content, soil micro-organisms, improves soil crumb structure and nutrient status of soil (Willumsen and Thorup, 2001) Investigations proved that application of green manuring significantly reduced the fruit rot incidence and enhanced the fruit yield and dry matter production.Green manures are rich in mineral, organic matters and bioactive compounds which help for better growth of plants and control of plant diseases (Nabin and Geetha, 2014) Legumes fix atmospheric nitrogen and mobilize less available nutrients from the soil; they also improve soil structure and decrease leaching losses of nutrients.

Neem oil is usually used as an insecticide but also has fungicide action. Although neem oil (or) water extracts of neem cake controls insects and pests, plant parasitic nematodes and Soil borne pathogens. (Pervaiz et al., 2003) Neem oil evaluated for their effects on vector activities, disease incidence and yield attributing characters during Rabi 2019-20 cropping season. It reduces the disease incidence using the doses at different intervals (Gur jar et al., 2012). Neem oil foliar spray after initiation of disease symptoms in order to have a higher profitable yield and higher economic return without health risk as well as environmental pollution.

\section{Materials and Methods}

The present work was carried out in the laboratory of the Department of Plant Pathology, Sam Higginbottom University of Agriculture, Technology and Sciences, Allahabad (U.P.) during Rabi season 2019-20. The experiment was conducted in Randomized block design (RBD) in field consisting of seven treatments union with three replicates. Two foliar sprays of neem oil @ $0.5 \%$ at 15 days interval, starting first spray at appearance of anthracnose symptoms. One plot per replication was maintained as the control. Five plants per treatment per replication were selected randomly and tagged; three leaves (bottom, middle and top) from main branch on each observation plant were selected for recording observations. Observations on foliage anthracnose disease intensity were recorded applying standard 0-9 grade disease rating scale (Mayee and Datar, 1986) one day before each spraying and last observation was recorded.

\section{Green manure preparation and application}

Green manure seeds of each plant species were sown directly into their respective field where appropriate and seeds of cowpea $(25 \mathrm{~kg} / \mathrm{ha})$, cluster bean $(10 \mathrm{~kg} / \mathrm{ha})$, sunhemp $(25 \mathrm{~kg} / \mathrm{ha})$, green gram $(15 \mathrm{~kg} / \mathrm{ha})$, black gram 
(15kg/ha), Dhaincha (25kg/ha) were sown and allowed to grow for about 60 days, before they reached to $50 \%$ flowering then they were incorporated into the soil. Therefore, the plots of green manures were allowed to decompose for 15days after incorporation. Then the chilli seedlings were transplanted in the respective field (Willumsen and Thorup, 2001)

\section{Raising and transplanting of Chilli seedlings}

The Chilli seeds were sown in pro trays which were filled with cocopeat and the local variety of chilli seeds were sown @ 3 seeds per cell at $1 / 4$ inch deep and the seeds were covered with potting mixture, water was sprinkled when required. After 5 weeks chilli seedlings were taken to the field while removing the seedlings, proper care was taken and transferred to the field with the spacing of 60 $\mathrm{X} 45 \mathrm{~cm}$ (row $\mathrm{X}$ row and Plant X Plant) (Gopakkali and Sharanappa, 2014).

\section{Foliar spray of neem oil}

Foliar spray of Neem oil @ 0.5\% was done after the first appearance of Colletotrichum disease symptoms followed by two sprays at 15 days of interval by hand sprayer.

\section{Isolation of Colletotrichum capsici}

Isolation of pathogen was done following the procedure mentioned by Ahmed et al., (2013).Infected leaf specimens were gathered from central research field SHUATS Allahabad. The leaf specimens were washed with tap water, the infected parts were cut into small pieces $(5 \mathrm{~mm})$, sterilized with $0.1 \%$ $\mathrm{NaOCl}$ for 2 min and washed in sterilized water for 3 times and dried between folds of purified filter paper. The washed leaf pieces were transferred to sterilized PDA plates and incubated at room temperature for 5 days. Mycelial bits were transferred to sterile Petri dishes containing PDA medium and pure cultures of the pathogens was maintained for further studies. The inoculated Petri plates were incubated at a temperature of $25 \pm 1^{0} \mathrm{c}$ and observed periodically for the growth of emerging fungus developed from diseased tissues. The hyphal growth of the fungus was then transferred to PDA slants and Petri plates and incubated at $25^{\circ} \mathrm{C} \pm 1^{\circ} \mathrm{c}$ and pure culture thus obtained through hyphal tip was maintained.

\section{Disease intensity}

Standard disease rating scale (0-9 scale) was used for accessing PDI of anthracnose of chilli given by Mayee and Datar (1986).

\section{Rating scale disease intensity}

No symptoms on the leaf or branch or fruit.

1 Small, irregular brown spots covering 1 percent or less area of the leaf or branch or fruit.

Brown, dirty, pin headed spots covering 1-10 per cent area on the leaf or branch or fruit. Dark brown, dirty black spots with blackish margin covering 1 per cent of the area of leaf or branch or fruit.

Dark brown, circular or irregular spots with blackish covering 26-50 per cent area of leaf or branch or fruit.

Dark brown, circular or irregular spots with blackish covering 51 per Cent and above area of leaf or branch or fruit. The per cent disease index (Chester, 1959 and Wheeler, 1969) was calculated as,

Sum of all individual disease ratings

Percent disease index(PDI) $(\%)=$ x 100 


\section{Benefit cost ratio}

Gross return was calculated by multiplying total yield with the market price of the produce. Cost of cultivation and cost of treatment imposition was deducted from the gross returns, to find out net returns and cost benefit ratio by following formula

$\mathrm{B}: \mathrm{C}=\frac{\text { Gross return }}{----------}$

Were, B: C -Benefit and Cost ratio (Hossain et al., 2010)

\section{Results and Discussion}

Result based on field experiment, the effectiveness of the soil, green manuring and foliar spray of neem oil on the plant growth parameters increases significantly as compared to control. The maximum plant height was observed in the treatment $\mathrm{T}_{4}-$ Sun hemp + neem oil $(49.92 \mathrm{~cm})$ followed $\mathrm{T}_{6}$ Dhaincha + neem oil $(49.13 \mathrm{~cm}), \mathrm{T}_{5}-$ Cluster bean + neem oil $(48.46 \mathrm{~cm}), \mathrm{T}_{1}$ - Cowpea + neem oil $(47.60 \mathrm{~cm}), \mathrm{T}_{2}$ - Black gram+ neem oil $(46.50 \mathrm{~cm}), \mathrm{T}_{3}-$ Green gram + neem oil $(46.30 \mathrm{~cm})$. While minimum of plant height was recorded in untreated control $(44.14 \mathrm{~cm})$. Hiremath et al., (2005) who observed and proved that green manuring gives more nutrients uptake to the soil for growth of the crop, significantly effective for growth of the plants and gives nutrients to the soil like N, P, $\mathrm{K}$. In case, of fruit length the maximum was recorded in $\mathrm{T}_{4}$ - Sun hemp + neem oil $(9.05$ $\mathrm{cm})$ followed $\mathrm{T}_{6}-$ Dhaincha + neem oil $(9.0$ $\mathrm{cm}), \mathrm{T}_{5}$ - Cluster bean + neem oil $(8.96 \mathrm{~cm})$, $\mathrm{T}_{1}$ - Cowpea + neem oil $(8.72 \mathrm{~cm}), \mathrm{T}_{2}$ - Black gram+ neem oil $(8.63 \mathrm{~cm}), \mathrm{T}_{3}-$ Green gram + neem oil $(8.6 \mathrm{~cm})$. While minimum of plant height was recorded in untreated control (7.09 $\mathrm{cm})$. Dileep and Shashikala (2009), Singh et al., (2014) also reported similar findings inchilli crop, thereby increasing the availability of nutrients, especially protein synthesis and significantly increases in number of fruits (Fig. 1 and 2; Table 1 and 2).

Table.1 Effect of green manuring and neem oil on anthracnose isease intensity (\%) of chilli at 30, 60 and 90 DAT

\begin{tabular}{|c|c|c|c|c|c|c|c|}
\hline \multirow[t]{2}{*}{ Sr.no } & \multirow[t]{2}{*}{ Treatments } & \multicolumn{6}{|c|}{ Average of 3 replicates } \\
\hline & & $\begin{array}{l}\text { Before } \\
\text { spray }\end{array}$ & $\begin{array}{c}\% \\
\text { reduction } \\
\text { over } \\
\text { control }\end{array}$ & $\begin{array}{l}1^{\text {st }} \text { spray of } \\
\text { neem oil at } \\
\text { 60DAT }\end{array}$ & $\begin{array}{c}\% \\
\text { reduction } \\
\text { over } \\
\text { control }\end{array}$ & $\begin{array}{l}2^{\text {nd }} \text { spray of } \\
\text { neem oil at } \\
\text { 90DAT }\end{array}$ & $\begin{array}{c}\% \\
\text { reduction } \\
\text { over } \\
\text { control }\end{array}$ \\
\hline $\mathbf{T}_{\mathbf{0}}$ & Control & 18.66 & & 34.93 & & 43.40 & \\
\hline$T_{1}$ & Cowpea + Neem oil & 18.16 & 26.35 & 25.37 & 27.36 & 33.36 & 23.13 \\
\hline $\mathbf{T}_{2}$ & Black gram + Neem oil & 17.40 & 29.44 & 21.50 & 38.44 & 29.57 & 31.86 \\
\hline $\mathbf{T}_{3}$ & Green gram + Neem oil & 18.13 & 26.48 & 22.16 & 36.55 & 31.56 & 27.28 \\
\hline $\mathbf{T}_{4}$ & Sun hemp +Neem oil & 15.0 & 39.17 & 20.60 & 41.02 & 25.79 & 40.57 \\
\hline$T_{5}$ & Clusterbean + Neem oil & 16.66 & 32.44 & 20.80 & 40.45 & 28.63 & 34.03 \\
\hline$T_{6}$ & Dhaincha + Neem oil & 15.26 & 38.11 & 20.76 & 40.56 & 26.63 & 38.64 \\
\hline & $\mathrm{SEd} \pm$ & 0.33 & & 0.60 & & 0.50 & \\
\hline & C.D (5\%) & 0.73 & & 1.31 & & 1.08 & \\
\hline
\end{tabular}


Table.2 Effect of green manuring and neem oil on plant growth and yield of chilli

\begin{tabular}{|c|c|c|c|c|c|c|c|}
\hline \multirow[t]{2}{*}{ Sr.no } & \multirow[t]{2}{*}{ Treatments } & \multicolumn{3}{|c|}{$\begin{array}{l}\text { Average of } 3 \text { replicates } \\
\text { Plant height }(\mathrm{cm})\end{array}$} & \multirow{2}{*}{$\begin{array}{c}\text { Fruit } \\
\text { length } \\
(\mathbf{c m})\end{array}$} & \multirow[t]{2}{*}{$\begin{array}{l}\text { Yield } \\
\text { t/ha }\end{array}$} & \multirow[t]{2}{*}{$\begin{array}{l}C: B \\
\text { ratio }\end{array}$} \\
\hline & & 30DAT & 60DAT & 90DAT & & & \\
\hline $\mathbf{T}_{\mathbf{0}}$ & Control & 11.26 & 24.65 & 44.14 & 7.09 & 4.94 & $1: 1.63$ \\
\hline $\mathbf{T}_{1}$ & Cowpea + Neem oil & 14.0 & 27.02 & 47.60 & 8.72 & 7.99 & $1: 3.14$ \\
\hline $\mathbf{T}_{\mathbf{2}}$ & $\begin{array}{l}\text { Black gram + Neem } \\
\text { oil }\end{array}$ & 13.5 & 26.69 & 46.50 & 8.63 & 7.22 & $1: 2.75$ \\
\hline $\mathbf{T}_{\mathbf{3}}$ & $\begin{array}{l}\text { Green gram + Neem } \\
\text { oil }\end{array}$ & 13.16 & 26.28 & 46.30 & 8.6 & 6.57 & $1: 2.42$ \\
\hline $\mathbf{T}_{4}$ & Sun hemp + Neem oil & 15.42 & 29.50 & 49.92 & 9.04 & 9.02 & $1: 3.67$ \\
\hline $\mathbf{T}_{\mathbf{5}}$ & $\begin{array}{l}\text { Cluster bean + Neem } \\
\text { oil }\end{array}$ & 15.0 & 28.06 & 48.46 & 8.96 & 8.40 & $1: 3.63$ \\
\hline \multirow[t]{3}{*}{$\mathbf{T}_{6}$} & Dhaincha + Neem oil & 15.33 & 29.26 & 49.13 & 9.0 & 9.0 & $1: 3.65$ \\
\hline & $\mathrm{SEd} \pm$ & 0.70 & 1.24 & 0.48 & 0.23 & 0.13 & - \\
\hline & C.D $(5 \%)$ & 1.53 & 2.70 & 1.05 & 0.51 & 0.27 & - \\
\hline
\end{tabular}

Fig.1 Effect of green manuring and neem oil on anthracnose disease intensity (\%) of chilli at 30, 60 and 90 DAT

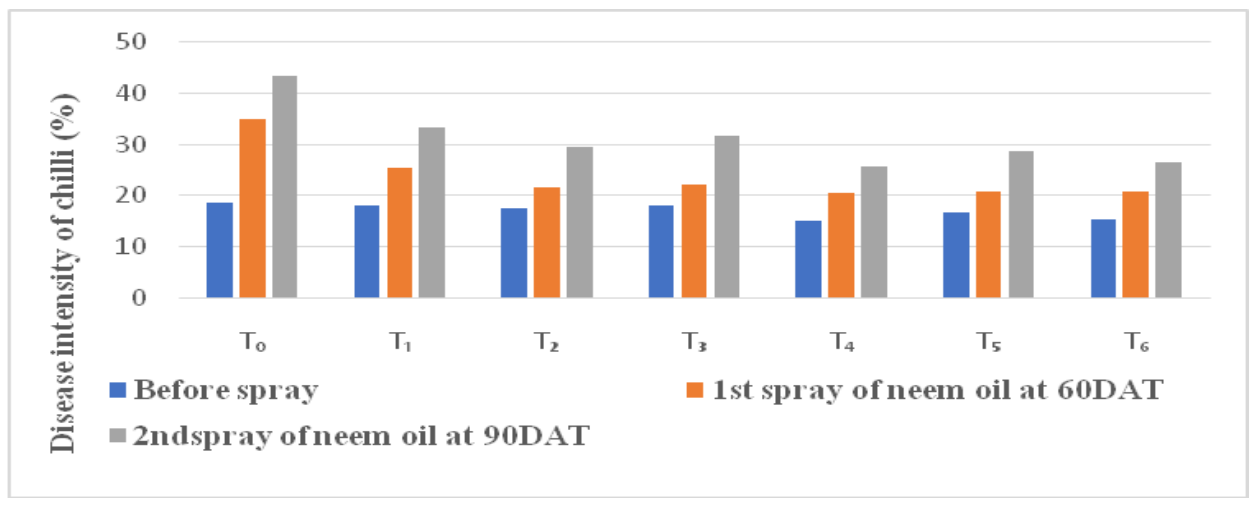

Fig.2 Effect of green manuring and neem oil on plant growth and yield of chilli

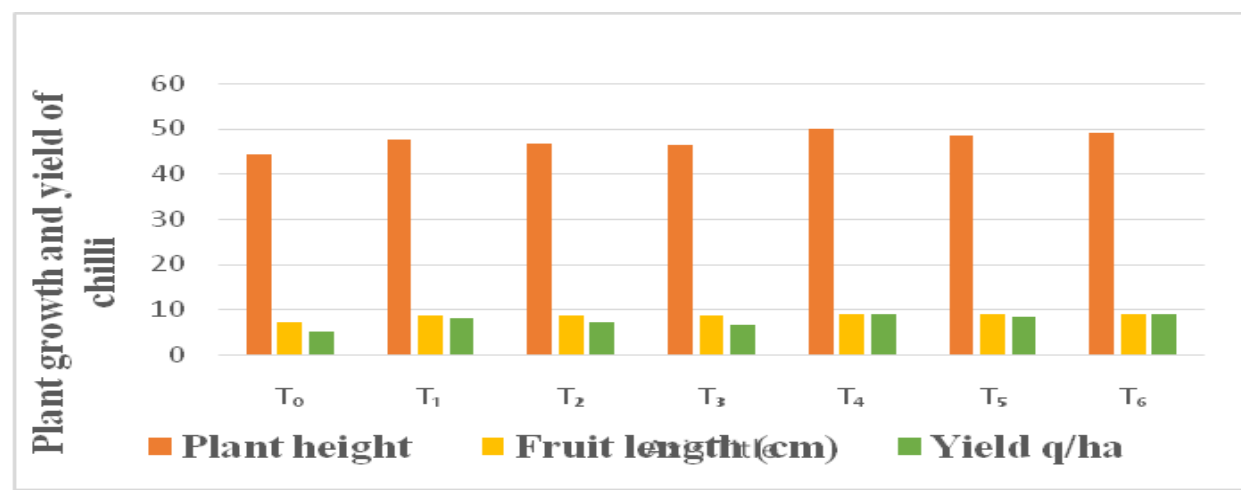




\section{Plate.1}
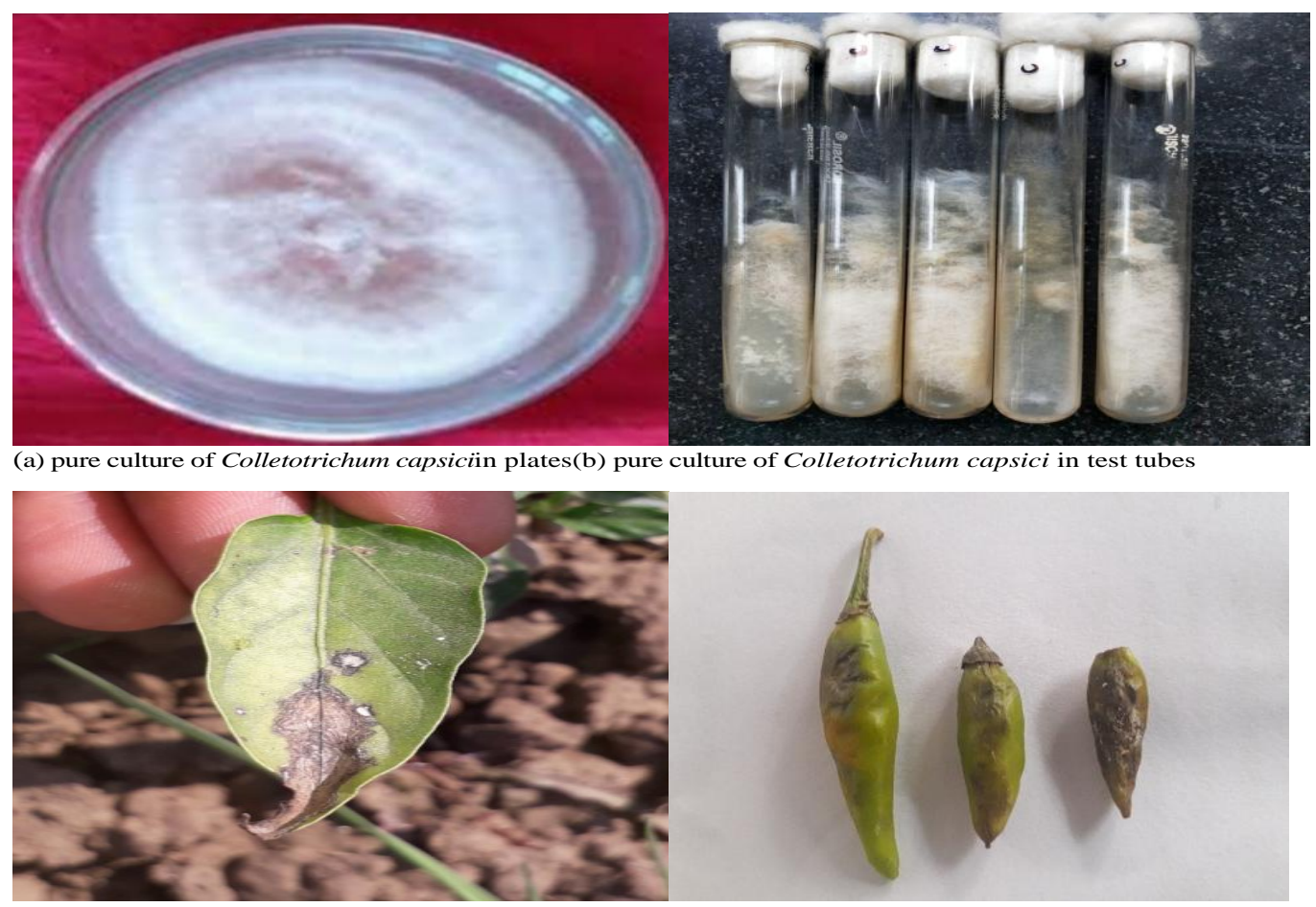

(c) Leaf spotof Chilli(d) Fruit rot of chilli

Maximum disease intensity was observed in $\mathrm{T}_{1}$ Cowpea + Neem oil (33.36\%), followed by $\mathrm{T}_{3}$ Green gram + Neem oil $(31.56 \%), \mathrm{T}_{2}$ Black gram + Neem oil $(29.57 \%), \mathrm{T}_{5}$ Cluster bean + Neem oil $(28.63 \%), \mathrm{T}_{6}$ Dhaincha + Neem oil $(26.63 \%), \mathrm{T}_{4}$ Sun hemp + Neem oil $(25.79 \%)$. while minimum of disease intensity was recorded in untreated control (43.40 \%). Ahmed et al., (2001) observes that the effective treatment of two sprays of neem oil, which recorded disease incidence over control followed by neem oil. Bunker et al., (2019)who observed, the foliar spray of neem oil was significantly effective to suppress the disease but, it was not effective for longer period due to less persistence period.

The maximum yield of chilli was recorded in the treatment was $\mathrm{T}_{4}$ Sun hemp+ Neem oil $(90.23 \mathrm{q} / \mathrm{ha})$ as compared to untreated control (49.47q/ha) and other was shown as $\mathrm{T}_{6}$ Dhaincha + neem oil (90.03q/ha), $\mathrm{T}_{5}$ - Cluster bean + neem oil $(84.07 \mathrm{q} / \mathrm{ha}), \mathrm{T}_{1}$ Cowpea+ Neem oil (79.97q/ha), $T_{2}$ Black gram+ Neem oil $(72.20 \mathrm{q} / \mathrm{ha}), \mathrm{T}_{3}$ - Green gram + neem oil (65.70q/ha). Hongal, (2001) reported significantly higher yield of chilli due to green manuring of sunnhemp than green manuring of green gram and cowpea.

From the present study it was concluded that, the severity of anthracnose of chilli disease can significantly be reduced by the use of Neem oil at least two times foliar spray after initiation of disease symptoms in order to have a higher profitable yield and higher economic return without health risk as well as environmental pollution. Sun hemp + Neem oil @ $0.5 \%$ proved that best effect in maximizing the plant growth and also yield as well. It can be concluded that Sun hemp + Neem oil @ $0.5 \%$ is the most economical, eco-friendly way to control anthracnose of chilli. Therefore, the farmers may be advised 
to take an integrated approach, which should be raised a profitable production without polluting the environment.

\section{References}

AgriosGN. (2006) Plant pathology 4th ed. Academic Press. London.

Ahmed D., Zara S., Baig H. (2013). In vitro analysis of antioxidant activities of Oxalis corniculate linn. Fractions in various solvents. Afr. J. Tradit. Complement Altern. Med; 10(1):158165.

Ahmed K., Hanumantha Rao V., Purnachandra P. (2001). Resistance of chilli cultivars to yellow mite, Polyphagotarsonemus latus Banks. Indian Journal of Agricultural Research.; 35:95-99.

Bunker, Tanwar and Aggarwal (2019). Management of Sorghum Anthracnose caused by Colletotrichum graminicola (Ces.) Wilson. Int.J.Curr.Microbiol. App.Sci., 8(10): 1371-1371.

Chester KS. How sick is the Plant? (1959). In J.G. Horsfall and A.E. Diamond Eds., Plant Pathology, Vol.1, The Diseased Plant. Academic Press, New York, 199242.

Dileep, S. N. and Shashikala (2009). Studies on the effect of different organic and inorganic fertilizers on growth, fruit characters, yield and quality of chilli (Capsicum annuum L.) cv.K-1. Int. J. of Agri. Sciences, 5(1): 229-232.

Gopakkali P, Sharanappa, (2014). Effect of organic production techniques on the growth, yield, quality and economics of chilli (Capsicum annuum L.) and soil quality in dry zone of Karnataka, Indian Journal of Agronomy.; 59(1):151-156.

Gopinath K, Radhakrishnan NV, Jayaraj J. (2006) Effect of propiconazole and difenoconazol on the control of anthracnose of chilli fruit caused by
Colletotrichum capsici. Crop Protection; 25:1024-1031

Gurjar, Shahida ali, Masood Akhtar, Kangabam Suraj Singh (2012). Efficacy of plant extracts in plant diseases management. Agricultural Sciences.

Hiremath, Anil more B.M., Chittapurand Chimmad (2005). Effect of Green Manuring and Forms of Phosphorus on the Productivity of Chilli + Cotton Intercropping System. Karnataka J.Agric.Sci., 18 (2): (297-301).

Hongal M.M., (2001). Effect of green manuring and levels of nitrogen on the performance chilli + cotton intercropping system. M.Sc. (Agri.) thesis, University of Agricultural Sciences, Dharwad

HossainM.D, AzizzulM.D, Masum, Prodhan. (2010). Development of integrated management approach for pod borer Helicoverpa armigera (Hubner) on chick pea, Bangladesh J. Agril; 35(2): 201-206.

Lydia C., Zacharia, S. (2012) Evaluation of biological, chemical and IDM modules for the management of anthracnose and die-back of chilli. Journal of Mycology and Plant Pathology, 42(4):435-438.

Mayee C.D., Datar V.V., (1986). Phytopathometry Tech. Bull-1 Marathwada Agriculture University, Parbhani, 66

Nabin Bhattaraj and Geeta (2014). Efficacy of invasive green manures and mycorrhiza on growth and yield of different legumes crops and study their antimicrobial properties. Shigan International college (SICOST).

Sahitya U., Deepthi R., Pedda D., Suneetha P., Krishna M.S.R (2014). Anthracnose, a prevalent disease in Capsicum. Department of Biotechnology, KL University, India. Acharya N. G. Ranga Agricultural Universiry, Hyderabad. Research Journal of Pharmaceutical, 
Biological and Chemical Sciences. 5(3):1583-1604.

Shovan L.R., Bhuiyan. M.K.A., Begum J.A., Pervez, Z. (2008) In vitro control of Colletotrichum dematium causing anthracnose of soybean by fungicides, plant extracts and Trichoderma harzianum. Int. J Sustain. Crop Prod; 3:10-17.

Singh C. K. A., Suchitand Devansu (2014).
Effect of organics on growth, yield and biochemical parameters of chilli (Capsicum annuum L.). IOSR Journal of Agriculture and Veterinary Science, 7(1): 2319-2372.

Wheeler, B.E.J. (1969). An introduction to plant diseases. John Wiley and sons, London.

\section{How to cite this article:}

Veeramreddy Srilekha, Sobita Simon and Sunil Zacharia. 2020. Effect of Green Manure and Neem Oil on Anthracnose Disease of Chilli (Capsicum annuит L.). Int.J.Curr.Microbiol.App.Sci. 9(12): 2329-2336. doi: https://doi.org/10.20546/ijcmas.2020.912.276 